\title{
Risk Evaluation in Blood Donation Using Failure Mode and Effective Analysis
}

\author{
Razaz M. Salih, Eltahir M. Husein, Elias Hassan
}

Department of Biomedical Engineering, Sudan University of Science and Technology, Khartoum, Sudan

Correspondence to: Razaz M. Salih, razazsalih-7@hotmail.com; Eltahir M. Husein, Altahir_33@yahoo.com; Elias Hassan, elias_siddig@hotmail.com

Keywords: Donation, Blood Product, Donor, Failure Mode and Effective Analysis, Adverse Event, Risk Priority Number

Received: February 16, $2021 \quad$ Accepted: April 9, $2021 \quad$ Published: April 12, 2021

Copyright (c) 2021 by author(s) and Scientific Research Publishing Inc.

This work is licensed under the Creative Commons Attribution International License (CC BY 4.0).

http://creativecommons.org/licenses/by/4.0/

\section{(c) (i) Open Access}

\section{ABSTRACT}

The recognition and management of risk in donation process and blood product is critical to ensure donor and patient safety. To achieve this goal, the failure mode and effects analysis (FMEA) is a convenient method; moreover it was used to prevent the occurrence of adverse events and look at what could go strong at each step. This study aimed to utilize FMEA in central blood bank in Khartoum to evaluate the potential risk and adverse event that may occur during the donation process. According to the severity, occurrence and the detection of each failure mode, the risk priority number (RPN) was calculated to determine which of the failures should take priority to find a solution and applying corrective action to reduce the failure risk. The statistical package for social sciences (SPSS) version 11 was used as descriptive and analytical statistics tool. The FMEA technique provides a systematic method for finding vulnerabilities in a process before they result in an error, and in this study a satisfactory outcome was reached.

\section{INTRODUCTION}

A blood bank is a center where blood gathered as a result of blood donation is stored and preserved for later use in blood transfusion [1], therefore the donor and patient safety must take the priority in managing the blood banks and other healthcare facilities. Blood donation is voluntary operation carried out with complete donor consent to save multiple lives. The selection of blood donor in simple principle should be safe for donor and not harm the recipient [2]. Blood donor selection is the first crucial step to ensure blood safety and reduces risk through the individuals with identified risks that may be associated with infection. The purpose of blood donor selection is to:

1) Protect donor safety by collecting blood only from healthy individuals to ensure recipient safety. 
2) Identify any factors that might make donor unsuitable.

3) Reduce the unnecessary deferral of safe and healthy donors.

4) Minimize the wastage of resources resulting from the collection of unsuitable donations [3].

According to the reasons of donation there are three types of blood donation:

1) Volunteer blood donation:

The most common type of blood donation that donor donates for any recipient in need.

2) Directed blood donation:

The patient receives the blood from his/her family members or friends with same blood group.

3) Autologous donation:

This type is very useful for a patient with a rare blood type, which a person donates blood for their own use before or during a scheduled surgery. Blood stored for up to 42 days and give back to the same individual if a need for transfusion arises. In this type of donation, the donor must be healthy enough to donate safely [4].

There are some conditions; an individual may exclude from donating blood such as

- Hemoglobin or hematocrit level is below what's safe for blood donation

- Blood pressure or pulse is too high or low

- The donor under treatment for a variety of illnesses like cancer

- Heart disease or certain blood diseases

- Cold or flu, had a recent blood transfusion

- Hepatitis, HIV/AIDS

- Certain international travel

- Organ/tissue transplants

- Pregnancy

- Sexually transmitted diseases

- Taking certain medications

- $\quad$ Bloodletting or cupping [4]

The risk management and root cause analysis is one of the clinical engineering disciplines [5], so, this paper will aim at that task.

The failure mode and effects analysis (FMEA) is an engineering technique used to protect the patient from known/potential failure errors or problems before occur [6]. FMEA was used in aerospace industry since 1960. In healthcare FMEA is one of patient safety tools that provide risk management and enhance the patient care environment, and makes the assumption that errors are preventable and predictable $[7,8]$.

FMEA is used in the blood bank and donation process to enhance and improve the quality of donation and blood product as well as warrantee the donor and recipient safety.

\section{RELATED STUDIES}

In study [9] the authors identified four failure modes with the highest risk priority numbers (RPNs) over 75 when applied the FMEA to preventing blood transfusion failures, so, identified factors that lead to blood transfusion failures in a general hospital setting, The rate of blood transfusion failures declined after they implemented FMEA method and established the corrective interventions at the hospital. The number of 77 failure modes were identified in study [10], and only 13 failure modes were identified as unacceptable risk, this cross-sectional study analyzed the failure mode and effects of blood transfusion in pediatric emergency process by a mixture of quantitative-qualitative method, the hazard score was determined based on hazard scoring matrix (a hazard score above 8) by multiplying severity by probability of failure occurrence also they used score from 1 to 5 . The failure modes and effects occurring throughout the whole process of blood transfusion were identified in study [11], Analysis has shown that five failure modes with the highest RPNs, and therefore the greatest risk, and they founded that the risks of blood transfusion and its underlying causes are reduced after implementation of FMEA.

By virtue of previous studies, FMEA sheet form has been used in this paper, also we get benefit from the statistical factors that used to collect the data. 
This study focused on identifying the potential failure mode that may occur during blood donation, and founding the corrective action for the failure modes with highest RPN.

\section{METHODE}

The objective of using FMEA is to look for all ways a process of blood donation can fail, or the technicians can make a mistake. As shown in Table 1 the failure modes collected from central blood bank in Khartoum (as case study) by doing a personal interview with multidiscipline staff work in donation department. They asked about the failure that may happen during the different donation procedure steps, also the voice recorder was used during interview to avoid the loss or lack of information. Most of the technical staff were busy because of the high load of work, however, they were very helpful and cooperative.

Table 1. Evaluation of Risk Priority Numbers (RPNs) including the severity, probability of occurrence and probability of detection score.

\begin{tabular}{|c|c|c|c|c|c|c|c|c|}
\hline 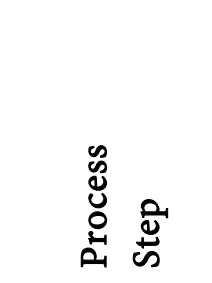 & 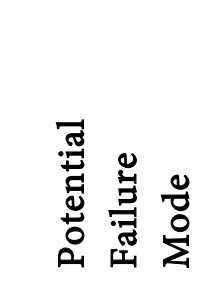 & 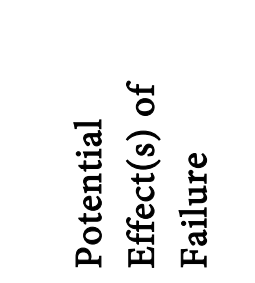 & 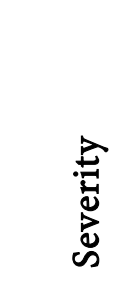 & 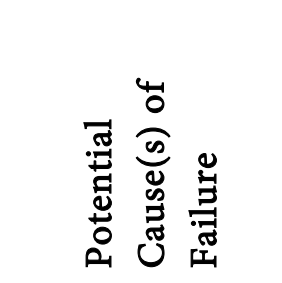 & 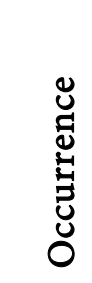 & 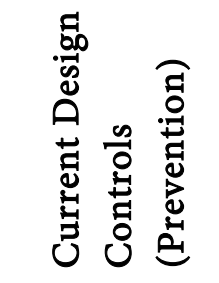 & 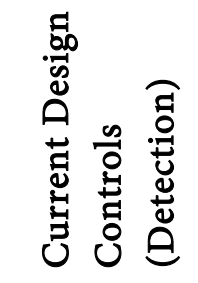 & 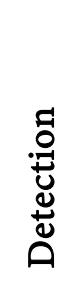 \\
\hline $\begin{array}{l}\text { Donor } \\
\text { Registration }\end{array}$ & $\begin{array}{l}\text {-Donor } \\
\text { register } \\
\text { without ID }\end{array}$ & $\begin{array}{l}\text {-Donor give } \\
\text { wrong name }\end{array}$ & 7 & $\begin{array}{l}\text {-In donor } \\
\text { registration not } \\
\text { ask for the ID }\end{array}$ & 2 & - & - & 9 \\
\hline $\begin{array}{l}\text { Medical } \\
\text { history } \\
\text { of donor }\end{array}$ & $\begin{array}{l}\text {-Donor fill } \\
\text { wrong } \\
\text { medical } \\
\text { information }\end{array}$ & $\begin{array}{l}\text {-Complication } \\
\text { during the } \\
\text { donation } \\
\text { process }\end{array}$ & 6 & $\begin{array}{l}\text {-In family } \\
\text { donation the } \\
\text { donor need to } \\
\text { help his } \\
\text { patient and he } \\
\text { don't want to } \\
\text { reject him as } \\
\text { donor }\end{array}$ & 5 & - & - & 5 \\
\hline \multirow{3}{*}{$\begin{array}{l}\text { Measure the } \\
\text { hemoglobin } \\
\text { level and } \\
\text { blood } \\
\text { grouping }\end{array}$} & $\begin{array}{l}\text {-Wrong } \\
\text { hemoglobin } \\
\text { reading }\end{array}$ & $\begin{array}{l}\text {-Fainting, } \\
\text { heart rate } \\
\text { acceleration }\end{array}$ & 4 & $\begin{array}{l}\text { Defect in } \\
\text { hemoglobin } \\
\text { analyzer } \\
\text { (heamocue) }\end{array}$ & 2 & $\begin{array}{l}\text { Quality } \\
\text { control }\end{array}$ & - & 2 \\
\hline & $\begin{array}{l}\text {-Wrong } \\
\text { blood } \\
\text { grouping }\end{array}$ & $\begin{array}{l}\text {-Blood bag } \\
\text { will tack } \\
\text { wrong blood } \\
\text { group label }\end{array}$ & 7 & $\begin{array}{l}\text { Problem in the } \\
\text { Monoclonal } \\
\text { Antibodies used }\end{array}$ & 2 & $\begin{array}{l}\text { Make } \\
\text { regrouping }\end{array}$ & - & 1 \\
\hline & $\begin{array}{l}\text {-Wrong } \\
\text { labeling } \\
\text { information }\end{array}$ & $\begin{array}{l}\text {-Sample } \\
\text { wasted }\end{array}$ & 5 & $\begin{array}{l}\text { Lack of } \\
\text { attention }\end{array}$ & 3 & $\begin{array}{l}\text { Developing } \\
\text { the staff } \\
\text { performance }\end{array}$ & & 1 \\
\hline
\end{tabular}




\begin{tabular}{|c|c|c|c|c|c|c|c|c|}
\hline \multirow{4}{*}{$\begin{array}{l}\text { Start } \\
\text { donation } \\
\text { Process }\end{array}$} & $\begin{array}{l}\text {-Confusion } \\
\text { between } \\
\text { Two donors } \\
\text { with same } \\
\text { first and } \\
\text { second } \\
\text { name }\end{array}$ & $\begin{array}{l}\text {-Donor will } \\
\text { tack wrong } \\
\text { code }\end{array}$ & 8 & $\begin{array}{l}\text { Call the donor } \\
\text { using first and } \\
\text { second name } \\
\text { only }\end{array}$ & 2 & - & $\begin{array}{l}\text { Check the } \\
\text { donors } \\
\text { names } \\
\text { during the } \\
\text { donation }\end{array}$ & 2 \\
\hline & $\begin{array}{l}\text {-Phlebotomy } \\
\text { with } \\
\text { continuing }\end{array}$ & -hemolysis & 6 & $\begin{array}{l}\text {-Donor have } \\
\text { weak vein }\end{array}$ & 3 & $\begin{array}{l}\text { Check donor } \\
\text { vein first }\end{array}$ & & 1 \\
\hline & $\begin{array}{l}\text { process and } \\
\text { changing the } \\
\text { needle } \\
\text { position }\end{array}$ & $\begin{array}{l}\text {-painful } \\
\text { process }\end{array}$ & 7 & $\begin{array}{l}\text {-Wrong } \\
\text { needle } \\
\text { insertion }\end{array}$ & 3 & $\begin{array}{l}\text { Train the } \\
\text { technician } \\
\text { well }\end{array}$ & - & 4 \\
\hline & $\begin{array}{l}\text {-Blood } \\
\text { shaker } \\
\text { device stop } \\
\text { working }\end{array}$ & $\begin{array}{l}\text {-blood } \\
\text { clotting }\end{array}$ & 4 & $\begin{array}{l}\text {-Lack of } \\
\text { attention }\end{array}$ & 4 & $\begin{array}{l}\text { Preventive } \\
\text { maintenance }\end{array}$ & - & 2 \\
\hline $\begin{array}{l}\text { Rest and } \\
\text { refreshment }\end{array}$ & $\begin{array}{l}\text { Donor stand } \\
\text { quickly after } \\
\text { donation } \\
\text { process }\end{array}$ & $\begin{array}{l}\text { Fall down, } \\
\text { pleading }\end{array}$ & 7 & $\begin{array}{l}\text { Donor refuse to } \\
\text { wait at least } 10 \\
\text { minutes }\end{array}$ & 5 & - & - & 4 \\
\hline
\end{tabular}

\section{FMEA PROCESS:}

All the process must follow the following steps:

1) Review the process

2) Brain storm for potential failure

3) List potential effects of each failure mode

4) Assign a severity, occurrence and detectability of each failure

5) Calculate the risk priority number (RPN)

6) Prioritize these failure modes based on the RPN

FMEA focused on whole blood donation steps, which identified as follow:

- Donor registration.

- Medical history of donor.

- Measure hemoglobin level and blood grouping.

- Start donation process.

- Rest and refreshment.

For each step the potential failure mode was identified, also defined the effect and all potential root of causes for each failure mode.

Severity (S) of each effect is selected based on the impact/danger to the patient, was rated in score from 1 to 10 (10 is catastrophic). Occurrence $(\mathrm{O})$ of the failure mode causes also rated in score from 1 to 
10 when 10 is inevitable. Detection (D) of failure mode depends on the current action available to detect or prevent the occurrence of the adverse events and tack score from 1 to 10 (10 means control certainly not to detect the problem).

The risk priority number (RPN) was calculated by multiplying the three factors $S, O$ and $D(1)$.

$$
\mathrm{RPN}=S \times O \times D
$$

Failure modes with the highest RPNs were those with the most severe outcomes, the highest frequency of occurrence, and/or the most difficult to detect.

\section{BLOOD DONATION STEPS}

The blood donation is one of the serial operations performed in blood bank. In central blood bank in Khartoum there are two types of donation: volunteer donation (the donor came to donate his blood without reverting) and family or directed donation (the donor comes to help one of his/her family). The scores of $\mathrm{S}, \mathrm{O}$ and $\mathrm{D}$ were identified by the technical staff in charge of concern department.

First step in FMEA; listed the blood donation process steps depend on the current situation in central blood bank in Khartoum and the potential failure modes and their effect were identified as follow:

\section{1) First step-Donor registration:}

Donor registration is important to provide some basic information by filling a donation form (name, address, age, etc.) in addition to other questions answered by Yes/No about the medical history. Founded that donor registered without asked about his/her personal ID, donor may register with wrong name and wrong personal information, specifically if he/her was rejected before as donor, and there is no control action to detect these action.

2) Second step-Medical History.

After the donor answer the questions about his medical history in registration form, he/her met a doctor for oral interview, Doctor made health assessment before the donation process by asking an advanced question about medical history of donor (age, weight, blood pressure, lifestyle, and disease risk factors). All of this information is confidential. In this step donor may give wrong information about his medical history and that happened in a family donation, because the donor needs to help his patient and refuse to exclude him. Founded that also there is no control action to avoid the donor complication may occur during donation as result of his/her wrong medical history.

3) Third step-Measure the hemoglobin level and blood grouping.

In this step donor entered to donation room. Hemoglobin level was measured as final step to accept or reject the donor. If the donor anemic or hemoglobin level was low (females must have a minimum hemoglobin level of $12.5 \mathrm{~g} / \mathrm{dL}(85 \%)$ and males must have a minimum level of $13.0 \mathrm{~g} / \mathrm{dL}(88 \%))$ the donor will be excluded. If wrong hemoglobin reading, that causes donor fainting or heart rate acceleration and that lead to stopping the donation process. To avoid the occurrence of this failure there is preventive maintenance applied. A Blood grouping also attended to label it in the blood bag using the donor name and the serial number of the registration form. If the blood grouping was wrong then the blood bag will be labeled with wrong blood grouping, but founded that there is multiple check point and regrouping process to avoid and detect these error.

4) Forth step-Start the donation process:

Once the pre-donation screening was finished, donor announced by his name and proceed to a donor bed where his/her arm will be cleaned with an antiseptic, and a professional will use a blood donation kit to draw blood from a vein in his/her arm. Sometimes, two donors with same first and second name founded and that may lead to ambiguity in blood grouping and serial number that already typed in blood bag, for that they always used the forth name. However, Phlebotomy (venous rupture) may occur because of weak in donor vein or other technical reasons, so the donor vein is always checked carefully.

5) Fifth step-Rest and refreshment.

The donation process and blood draw take from 6 to 10 minutes. After blood donation kit was re- 
moved, donor must tack rest for at least 10 minutes. Donor may press and needs to go quickly and refuse to wait, and that may cause pleading or he fall down and hurt himself, so, staff observed the donor to avoid that.

\section{ASSESSING RISKS}

All the previous stages of donation process take from 60 to 90 minutes depends on the amount of donors in central blood bank. The severity, occurrence, detectability score for each failure mode and the entire potential failure mode were defined by the technical and professional staff, this subjective judgment was based on their knowledge and experience. See Table 1.

The presence of current design control either for detection or prevention was affected on the detectability and occurrence scores respectively, that resulted in an obvious reduction and tack scores in range from 1 to 3, conversely, the failure mode resulted from donor registration without ID got on score 9 in detection because the absence of the current control to detect the error, However that also marked on the final results of RPNs. There is no definitive RPN threshold to decide which areas should receive the most attention; this depends on many factors, including process standards, legal or safety requirements, and quality control. According to these factors, the RPN: 60 have been defined in this study as maximum weight for the accepted failure modes.

\section{RESULTS}

Blood donation is a major important process where appropriate risk management leads to significant improvement in the quality of services and donor safety. FMEA sheet form was used to manage and organize the failure mode in each donation step. Seven failure modes were founded in the whole process, the effects and causes of each failure mode were identified. Risk priority numbers (RPNs) were calculated according to Equation (1), failure modes with the highest risk priority numbers were identified and tock the priority to find solution and corrective action to reduce the risk. The overall RPN scores ranged from 6 to 150 among which, four failure modes were associated with RPNs over 60 . The data analysis indicates that failures with the highest RPNs were: donor registration (RPN: 126), medical history of donor (RPN: 150), Phlebotomy lead to patient pain (RPN: 84) and donor stand directly after donation (RPN: 140). See Table 2.

Table 2. Failure mode and RPNs scores.

\begin{tabular}{cccccc}
\hline No. & FAILURE MODE & S & O & D & RPN \\
\hline 1 & Donor Register without ID & 7 & 2 & 9 & 126 \\
2 & Donor Fill Wrong Medical Information & 6 & 5 & 5 & 150 \\
3 & Wrong Hemoglobin Reading & 4 & 2 & 2 & 16 \\
4 & Wrong Blood Grouping & 7 & 2 & 1 & 14 \\
5 & Wrong Labeling Information & 5 & 3 & 1 & 15 \\
6 & Confusion Between Two Donors with Same First and Second Name & 8 & 2 & 2 & 32 \\
7 & Phlebotomy Lead to Hemolysis & 6 & 3 & 1 & $\mathbf{1 8}$ \\
8 & Phlebotomy Lead to Patient Pain & 7 & 3 & 4 & $\mathbf{8 4}$ \\
9 & Blood Shaker Device Stop Working & 4 & 4 & 2 & $\mathbf{3 2}$ \\
10 & Donor Stand Quickly after Donation & 7 & 5 & 4 & $\mathbf{1 4 0}$ \\
\hline
\end{tabular}


The other failure mode with RPN under 60 defined as acceptable error, they were: wrong hemoglobin reading (RPN: 16), wrong blood grouping (RPN: 14), wrong labeling information (RPN: 15), confusion between two donors with same first and second name (RPN: 32), Phlebotomy lead to hemolysis (RPN: 18) and Blood shaker device stop working (RPN: 32).

\section{DISCUSSION}

Founded that the donor registration without personal identity document ID lead to impersonation because individual may be rejected previously as acceptable donor and that may cause a lot of problem, moreover this procedure was not available in central blood bank in Khartoum. Donor registration with a personal ID will warrant the recipient safety. This failure mode marked as high risk because there is no detection action to detect the failure, thus, the detection score given was 9, see Table 2. The donor registration form must be modified and the national number of donor must be added.

In this study failure that result of wrong medical history identified as high risk, that may predispose the donor to immediate or long-term harm, affect the safety or quality of the product derived from the blood or compromise patient safety. To reduce the effect of this failure donor must aware of the gravity of the situation and sign on a pledge under his responsibility about all medical history information. For regular donors the computerized history database will be helpful and more organized and easier to manage the risk.

As well, problems with phlebotomy are common occurrence during blood donation process. That may occur during lack in the experience of the technician. There is a possibility of feeling severe pain as a result of the wrong needle insertion or the appearance of bruises in its place, these bruises, and their color ranges from yellow, blue and even purple. The full staff training is very important to eliminate the aberrance of these problems especially for new staff.

Donor rest and refreshment most important for donor to ensure safety that called post-donation care. Founded that some donor stand up quickly after removing the donation kit, some individuals tell employee that he/she so busy, and others tell that they always go quickly after donation but most of them suffered from bleeding or may fall down in the stairs and that may cause serious injury. In this stage of donation process the refreshment area must be prepared in central blood bank in Khartoum, donor must wait there for at least 10 minutes then encourage donor to drink fluids and instruct him to drink adequate fluid during the day following donation, and avoid strenuous exercise or lifting anything heavy for 4 hours.

The failure modes with RPNs less than 60 were defined as accepted errors. This failure is already controlled and/or easy to detect, so, not affecting the result because this study only focused on the failure modes with RPNS over 60 and not affected with extreme values.

To ensure the donor and patient safety in central blood bank, using of Risk Management Information System (RMIS) will be helpful. This system is used to support expert advice and cost-effective information management solutions around key processes such as risk identification and assessment, risk control and risk financing.

\section{CONCLUSION}

FMEA is a proactive technique that helps to identify evaluation of donor safety in blood bank; it is a systematic method for finding vulnerabilities in a process before they result in an error. In this study, the corrective actions suggested for high-risk failure mode were convincing and satisfactory.

\section{ACKNOWLEDGEMENTS}

This article is a part of $\mathrm{PhD}$ thesis in biomedical engineering, Sudan University of Science and Technology. We are grateful to the central blood bank staff in Khartoum for their cooperation.

\section{CONFLICTS OF INTEREST}

The authors declare no conflicts of interest regarding the publication of this paper. 


\section{REFERENCES}

1. Hillyer, C.D. (2007) Blood Banking. In: Blood Banking and Transfusion Medicine: Basic Principles and Practice, Elsevier Health Science, Philadelphia, PA, 887.

2. Barbara, J.A.J., Regan, F.A.M. and Contreras, M. (2008) Blood Donor Selection and Qualification. In: Transfusion Microbiology, Cambridge University Press, New York, 390.

3. World Health Organization (2013) Blood Donor Selection: Guidelines on Assessing Donor Suitability for Blood Donation. United States Centers for Disease Control and Prevention (CDC).

4. The America's Blood Centers Website (2012). http://www.americasblood.org/donate-blood/blood-donation-101.aspx

5. Dyro, J.F. (2004) Clinical Engineering Handbook. Elsevier's Science and Technology Rights, Department in Oxford, UK Academic Press, 674.

6. Stamatis, D.H. (2003) FMEA A General Overview. In: Failure Mode and Effect Analysis. FMEA from Theory to Execution, ASQ Quality Press, Milwaukee, WI, 488.

7. Myers, S. (2011) Overview of Hospital Accreditation and Patient Safety. In: Patient Safety and Hospital Accreditation: A Model for Ensuring Success, Springer Publishing Company, New York, 326.

8. Paparella, S. (2007) Failure Mode and Effects Analysis: A Useful Tool for Risk Identification and Injury Prevention. Journal of Emergency Nursing, 33, 367-371. https://doi.org/10.1016/j.jen.2007.03.009

9. Najafpour, Z., Hasoumi, M., Behzadi, F., Mohamadi, E., Jafary, M. and Saeedi, M. (2017) Preventing Blood Transfusion Failures: FMEA an Effective Assessment Method. BMC Health Services Research, 17, 453. https://doi.org/10.1186/s12913-017-2380-3

10. Dehnavieh1, R., Ebrahimipour, H., Taleghani, Y.M., Najar, A.V., Hekmat, S.N. and Esmailzdeh, H. (2015) Proactive Risk Assessment of Blood Transfusion Process, in Pediatric Emergency Using the Health Care Failure Mode and Effects Analysis (HFMEA). Global Journal of Health Science, 7, 322-331. https://doi.org/10.5539/gihs.v7n1p322

11. Lu, Y., Teng, F., Zhou, J., Wen, A. and Bi, Y. (2013) Failure Mode and Effect Analysis in Blood Transfusion: A Proactive Tool to Reduce Risks. Transfusion, 53, 3080-3087. https://doi.org/10.1111/trf.12174 